

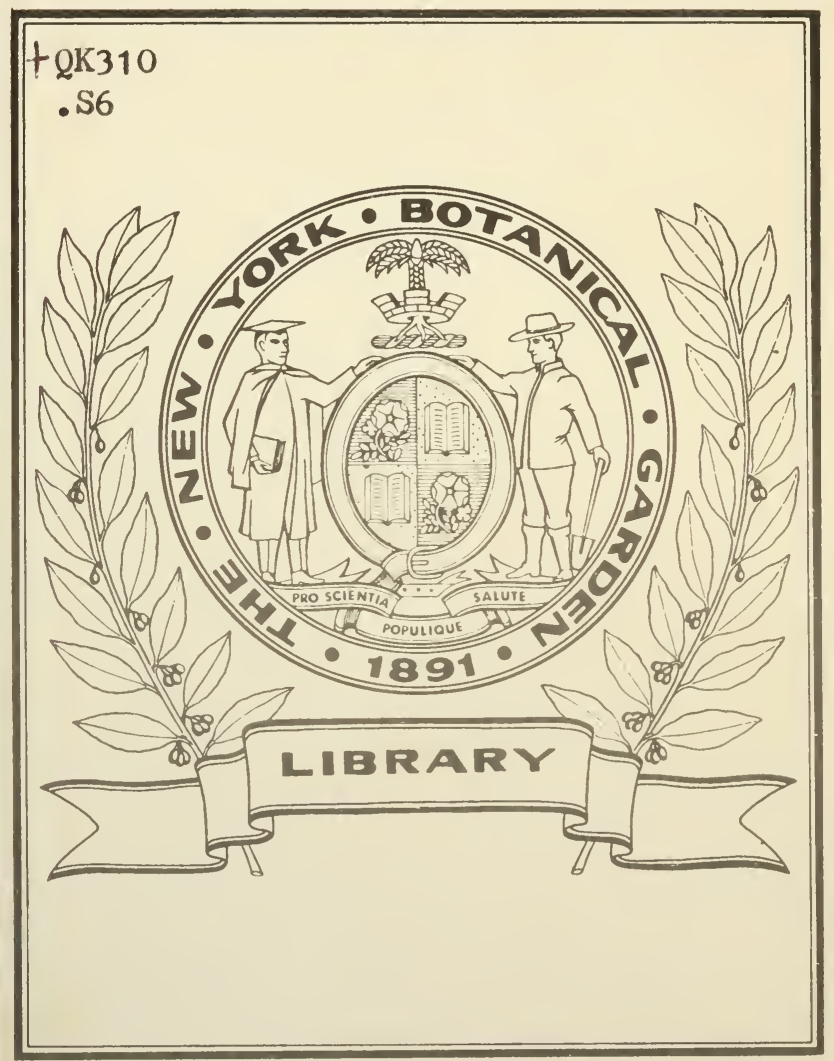




Flora Vectiana. 


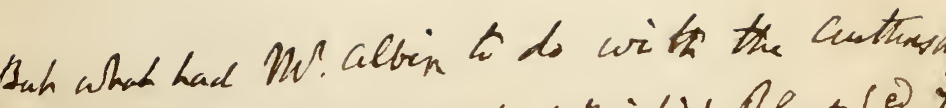

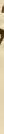
W.2.iv.k.433 is i catalo juor as

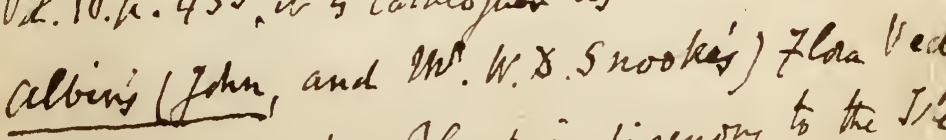
an arrangement of Mant indigenong to the Jis of wight.8vo 1823 . 


\title{
Flora Vectiana:
}

BEING

\section{AN ARRANGEMENT}

OF

\section{THE MORE RARE AND INTERESTING}

\section{㹱lants}

\author{
INDIGENOUS TO
}

\section{THE ISLE OF IVIGHT.}

"y. "In? Znow Snooke." See Zlou Vedeinsis by the late

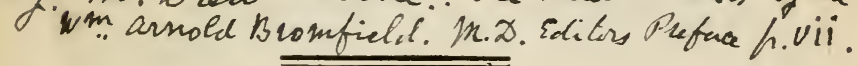

"6_ unnumber'd flow'rs,

The negligence of Nature, wide, and wild;

Where undisguis'd by mimic Art, she spreads

Unbounded beauty to the roving eye."

Thomson.

\section{O N D O N :}

PRINTED BY RICHARD TAYLOR, SHOE-LANE。

1823.

\section{LIBRARY}


56 


\section{P R E F A C E.}

IN offering to the Public this Flora of the Isle of $W$ ight, the Editor is induced to entertain a hope that it may be found useful, both by contributing to the pleasure and improvement of those who may make it a companion in their excursions, and by conducing in some degree, however humble, to the promotion of the delightful and interesting science of Botany. The utility of local Floras for this purpose has been recognised by the most distinguished Naturalists; and, if authorities were necessary, we might mention the Flora Tonbrigiensis of Mr. T. F. Forster, and The Botanists' Guide by Messrs. 'Turner and Dillwyn; to the latter of which works the Editor is happy to ackuowledge his obligations.

To those who take pleasure in admiring and studying the works of Nature, no occupation will 
seem more congenial with the leisure and enjoyment of a sojourn in the country, or of a visit to any spot distinguished by the beauty of its scenery, than that of examining the natural productions which it presents to their view. The plants which adorn and characterize a picturesque country, impressed on the recollection by that attention which the Botanist is led to bestow on them while enjoying his rambles, contribute largely to the stock of delightful associations which he carries away with him, and often call up the remembrance of the scenes in which lie observed them. And in the intervals of rest, or of unfavourable weather, he may furnish himself with agreeable occupation, in examining such as are new to him.

To the proficient in the science, such a list will also be useful, in saving his time by directing him to the places of growth of such plants as he may wish to obtain : and we shall be happy if our imperfect labours should tempt him to record what have escaped our notice, and which we shall thankfully insert in future editions.

"Botany," says the venerable Professor Martyn, " is not to be learned in the closet; you must go forth into the garden or the fields, and there become familiar with Nature herself, with that beauty, order, 
regularity, and inexhaustible variety which is to be found in the structure of vegetables, and that wonderful fitness to its end, which we perceive in every work of creation, as far as our limited understandings and partial observations give us a just view of it." And we shall, we trust, contribute in no small degree to the gratification of the Botanist, should we induce him to pursue his favourite study amidst the delightful scenery of the Isle of Wight, where at every turn he will enjoy a two-fold pleasure, derived at once from the investigation of nature, and the varied prospects of a beautiful ccuntry. 


\section{EXPLANATION.}

The following Arrangement has been made according to the Classes to which the different plants belong in the Linnæan System, which method has been considered as more satisfactory to the Botanist than that of placing the different Genera in alphabetical order.

The first name is that of the Genus, the second that of the Species, after which will be found the most common English name of the plant, with its general habitat, or place of growth; and when any particular place is specified, the name of the person who has there observed it, is commonly annexed.

Observations respecting the peculiarities or the virtues of some plants are contained in notes at the bottom of the page; which notes have been selected chiefly from "An Arrangement of British Plants," by William Withering, Esq. F.L.S. 


\section{Flora Vectiana.}

\section{MONANDRIA.}

Chara hispida. Prickly Stonewort.

Ditches in the marsh near Easton, plentifully.

Salicornia herbacea. Jointed Glasswort, or Marsh Samphire.

Abundant on the muddy shores of the Medina, Yar, and Brading Harbour ${ }^{1}$.

\section{DIANDRIA.}

Circas lutetiana. Enchanter's Nightshade.

Woods and shady lanes. In the lanes west and south of Blackwater. W.D. Snooke.

1 From the ashes of this plant a fossil alkali is obtained, which is in great request for making soap and glass. It is chiefly made on the coast of the Mediterranean, and is called soda. The whole plant has a saltish taste, and is greedily devoured by cattle. 
Veronica montana. Mountain Speedwell.

"Wood between Newport and Ryde; and at Shanklin." D. Turner.

N.B. Several other species of Veronica are common in the island.

Utricularia vulgaris. Greater Bladdersnout, or Hooded Water Milfoil.

Ditches in the marsh near Easton, plentifully. Ligustrum vulgare. Privet.

In hedges and thickets, abundantly ${ }^{2}$.

Orchis ustulata. Dwarf Orchis.

"Freshwater, near the cliffs." D. Turner.

Opirrys spiralis. Ladies-traces.

Near Carisbrooke Castle, Colwell, and Freshwater. Sir Nash Grose's grounds near Ryde. - apifera. Bee Orchis.

Carisbrooke, and Steephill. Pulteney. In the meadow at St. Boniface. W.D. Snooke.

Foot of the downs near Freshwater. Mrs. Rushworth.

Serapias latifolia. Bastard Hellebore. [Epipactis. Sm. "Between Shanklin and Godshill." J. Woods jun.

The berries are filled with a violet pulp, from which a rosecoloured pigment may be prepared. It is planted to make hedges, or commonly to thicken thorn hedges; it grows fast, and may be raised from cuttings. It bears the smoky atmosphere of large towns. If the berries are gathered as soon as they are ripe, and used with the addition of alum, they will dye wool and silk of a good and durable green : the leaves are bitter, and slightly astringent. Oxen, goats, and sheep eat it; horses refuse it. 
Serapias palustris. Marsh Helleborine.

Banks in Colwell Bay. Marsh near Compton.

Lema trisulca. Iny-leaved Duck-meat.

Ditches in the marsh near Easton, and about Sandown, in abundance.

\section{TRIANDRIA.}

Valeriana rubra. Red Valerian.

Yarmouth Castle, plentifully; together with the variety flor. albis.

\section{Locusta. Blue Valerian.}

Var. foliis dentatis, by the Finger Post at the junction of the Yarmouth and Freshwater road.

"Fields at Shanklin, Luccomb, and Carisbrooke, always mixed with the common Locusta." $D$. Turner.

Bryonia dioica. Red Bryony, or Wild Vine.

In hedges, \&c., rather common ${ }^{3}$.

Ir Is fotidissima. Stinking Gladwyn. Stinking Flag.

Between St. Lawrence and Steephill. Common in the island, on hedge banks and sloping yround. Scırpus multicaulis. Many-stalked Club Rush.

"Bog at Freshwater." D. Turner.

3 The root is purgative and acrid; a dram of it in substance, or half an ounce infused in wine, is a full dose. A decoction made with one pound of the fresh root is the best purge for horned cattle. Two or three of the berries have been eaten without any observable effects. Goats eat it; horses, cows, sheep and swine refuse it. 
Scirpus setaceus. Least Rush.

Marsh near Easton.

sylvaticus. Wood Club-grass.

"Under the Cliff at Shanklin." D. Turner.

Carex paniculata. Great Panicled Sedge.

- Marsh on Colwell Heath.

- pendula. Pendulous Sedge.

Abundant about Shanklin Chine. "Near Ryde."

D. Turner.

hirta. Hairy Sedge.

Banks in Totland Bay.

- flava. Tawny Sedge.

Var. (C. fulva.) "Bog at Freshwater." D. Turner. extensa. Long Bracteated Carex.

Var. (C. QEderi of E. Bot. 1773.) "Wood between Ryde and Newport." D. Turner. distans. Loose Sedge.

In the bog at the source of the Yar.

lavigata. Beaked Carex.

"Wood between Ryde and Newport." D. Turner. Typina latifolia. Great Cat's-tail.

About the Medina and Yar, in plenty. Sparganium natans. Floating Bur-reed.

In the Medina and Yar, in abundance.

Minium lendigerum. Panic Millet.

"Near Ryde." J.Woods jun.

Agrostris alpina. Bristle-leaved Bent-grass.

(A. setacea $F l$. Brit.) About Colwell, Hill Farm, and Freshwater, not unfrequent. "Apse Heath, and Bleak Down." D. Turner. 
Aira aquatica. Water Hair-grass.

Pond near the village of Pann.

Ruscus aculeatus. Knee Holly, or Butcher's Broom.

Banks near West Cowes. Between Newport and Cowes, near the Horse Shoe. Between Weston and the High Down.

Pos rigida. Hard Meadow-grass.

Shide Chalk-pit, \&c., rather common throughout the island.

— maritma. Sea Meadow-grass.

In abundance near Yarmouth and Brading.

Dactyus stricta. Smooth Cocksfoot-grass.

Yarmouth, in abundance.

Festuca rubra. Purple Fescue.

Spit at Norton.

elatior. Tall Fescue.

Common on the coast in argillaceous soils. First noticed by $\mathrm{D}$. Turner.

- loliacea. Spiked Fescue.

By the side of the Medina between Newport and Shide.

Brosus racemosus. Smooth Brome-grass.

"Freshwater." D. Turner.

- erectus. Upright Perennial Brome-grass.

"Luccomb." D. Turner.

Avexa fatua. Bearded Wild Oats.

Fields about Carisbrooke, plentifully; and rather common in the island.

- pubescens. Rough Oat-grass.

"Common about Luccomb, Carisbrooke, Freshwater, \&c." D. Turner. 
Avena pratensis. Meadow Oat-grass.

Shide Chalk-pit, "Luccomb, \&c. not uncommon."

D. Turner.

Arundo arenaria. Sea Mat-weed, Sea Reed, or Marram.

On the sea shore near Ryde ${ }^{4}$.

Triticum loliaceum. Dwarf Sea Wheat-grass.

"Yarmouth." E. Forster jun.

\section{TETRANDRIA.}

Dipsacus sylvestris. Wild Teasel.

By hedge sides. In High-wood Lane near Pidford. W. D. Snooke.

Scabiosa columbaria. Small Scabious.

About Carisbrooke abundantly; and in calcareous soils throughout the island.

Asperula cynanchica. Squinancy-wort.

Carisbrooke Castle, and on all the chaiky downs, in abundance.

Galiun cruciatum. Cross-wort.

In hedges and wood sides, very common.

tricorne. Corned Bed-straw.

" On fields near Carisbrooke." D. Turner.

4 This plant grows only on the very driest sand upon the sea shore, and prevents the wind from dispersing the sand over the adjoining fields. Many a fertile acre has been covered with sand and rendered useless, which might have been prevented by sowing the seeds of this plant upon the shore. It is planted on some of the flat coasts of Norfolk to repel the sea; and as soon as it takes root a sand hill gathers round. The inhabitants of Newborough in Anglesea make it into mats and ropes. 
Rubia tinctorum. Wild Madder.

Common in hedges in most parts of the island.

First noticed by J. Woods jun. ${ }^{5}$

Cenruxculus minimus. Bastard Pimpernel.

Heath at Colwell, plentifully.

Mrrica gallica. Dutch Myrtle.

Apse Heath, plentifully ${ }^{6}$.

Potanogeton pusillum. Small Pond-weed.

Ditches in the marsh near Easton.

pectinatum. Fennel-leaved Pond-weed.

With the above, in abundance.

Ruppia maritima. Tassel Pond-weed.

Ditches in the salt marsh near Yarmouth, in the greatest abundance.

Cornus sanguinea. Dogberry-tree.

Woods and hedges, not uncommon 7

Urtica dioica. Common Stinging Nettle.

Ditch banks, amongst rubbish, \&c. ${ }^{8}$

5 Dr. Horne pronounces Madder to be a powerful emmenagogue. The root yields a valuable and subtile red colour.

6 The northern nations formerly used this plant instead of hops; but unless it be boiled a long time it is apt to occasion head-ache.

7 The wood is very hard and smooth, fit for the purposes of the turner. The leaves change to a blood-red in autumn. The berries are bitter and styptic; they dye purple. A new kind of oil has been discovered in the berries: they are laid in a heap to soften and heat, when by pressure a fat oil may be procured, of a clear green colour, without smell or taste, and well adapted for either salads or lamps.

B The stings àre curious microscopic objects : they consist of 
Betula alba. Birch-tree.

Woods, \&c. in moist situations ${ }^{9}$.

- Alnus. Alder.

In low marshy situations ${ }^{10}$.

Ilex Aquifolium. Holly or Holm.

In hedges, \&c. "1

exceedingly fine-pointed, tapering, hollow substances, with a perforation at the point of each, and a bag at the base. The sting readily punctures the skin, and an acrimonious fluid is forced up from the bag, into the wound, and produces the stinging effect. The stalks may be dressed like flax or hemp, for making cloth or paper. An excellent cotton, proper for the manufacturer, may be obtained from this common and useful plant. Woollen stuffs may be dyed a beautiful and permanent green with the juice of nettles only. The roots boiled with alum will dye yarn a yellow colour.

Asses are fond of it, and cows eat the leaves when a little withered.

9 The wood is firm, tough, and white; women's shoe-heels, clogs, and packing-boxes are made of it. If a hole be bored into the tree when the sap rises in the spring, a sweet liquor distills from it, which properly fermented, with the addition of sugar, makes a pleasant wine.

10 Alder will not live in a chalky soil. It is easily propagated by seeds, but not by slips or cuttings. The wood is soft, but endures a long time under water: women's shoe-heels, clogs, cogs for mill-wheels, and various articles of the turner, are made of it. The bark yields a red colour; and with the addition of copperas, a black. 'The catkins dye green. The whole plant is astringent. If planted in a low meadow, the ground will become boggy ; whereas if Ash be planted, the roots of which penetrate a great way near the surface, the ground will become firm and dry.

11 All the varieties which gardeners reckon, amounting to 40 or 


\section{PENTANDRIA.}

Mrosotis palustris. Water Mouse-ear Scorpion-grass.

In moist ditches, not uncommon.

arvensis. Field Mouse-ear Scorpion-grass.

Dry pastures and gardens; rather more common than the preceding.

Cynoglossum officinale. Great Hound's-tongue.

Near the shore between St. Lawrence and Bonchurch, plentifully. W. D. Snooke. ${ }^{12}$

Pulmonaria angustifolia. Bugloss-cowslips.

Copse by the Medina below Newport, in plenty. Wood between Wootton Bridge and Ryde, in great abundance. Mr. Griffith, D. Turner, Sc.

50 , are derived from this one species, and depend on the variegations of the leaves or thorns, and the colour of the berries. It makes an impenetrable fence, and bears cropping: the beauty of its verdure, or of its scarlet berries, never suffers from the severest of our winters. The wood is used for veneering, and sometimes stained black to imitate ebony : cogs for mill-wheels are also made of it.

The Holly is peculiarly valuable, as flourishing with great beau'y under the shade and drip of the more lofty deciduous tribes. Withering.

12 Both the root and leaves have been suspected to possess narcotic properties, but some will not admit the fact. Its scent is very disagreeable, and muel resembles that of mice; especially after it has been gathered half an hour. If gathered when in full vigour, bruised, and laid in any place frequented by rats and mice, they will immediately forsake the premises. 
Pulmonaria virginica.

In a wood through which the road passes, about two miles and a half from Newport to Ryde. Mr. Griffith.

Sympnyqum officinale. Common Comfrey.

Banks of the Medina near Newport, Freshwater, Afton, and Sandown, rather common ${ }^{13}$.

Borago officinalis. Common Borage.

At Norton, and near Brading. At Godshill. W. D. Snooke.

Menyanthes trifoliata. Water Trefoil.

In the marsh near Compton, and in the marsh near Easton, in great abundance.

Lysimacnia vulgaris. Yellow Loosestrife, or Willow-herb.

In the marsh near Easton.

Avagamis tenella. Bog Pimpernel.

Heath at Colwell, and many other places in the parish of Freshwater, in plenty. Apse Heath. Coxvolvulus Soldanella. Sea Bindweed.

Spit at Norton, and Sandown Bay.

Campandea Trachelium. Great Throatwort, or Canterbury Bells.

Hedge between Idlecomb and Shorwell. glomerata. Little Throatwort.

Afton and Freshwater down, in plenty.

13 The particles of the pollen appear in the microscope like two globules united together. The leaves give a grateful flavour to cakes and panada, and the young stems and leaves are excellent when boiled. 
Campanula hybrida. Lesser Venus's Looking-glass, or Corn Bell-flower.

Field near Lake.

JASIONE montana. Hairy Sheep's Scabious.

Apse Heath, and under the cliff at Shanklin.

Verbascum Thapsus. Great Mullein.

Between Cowes and Newport. Common in most parts of the island.

nigrum. Black Mullein.

Near Arreton and Merston. W.D. Snooke.

Datura Stramonium. Thorn-apple, or Prickly Pear.

"Ryde." S. Woods.

At Godshill. W. D. Snooke. ${ }^{14}$

Hyoscyanus niger. Common Henuane.

Near the Hotel at Ventnor; and at St. Lawrence, in plenty. W. D. Snooke..$^{15}$

14 At night, the leaves particularly the upper ones, rise up and inclose the flowers. The seeds or leaves taken internally bring on tremors, delirium, \&c. Acetous or citric acid is an antidote to the poison. This plant has lately acquired attention by its alleged efficacy in alleviating fits of spasmodic asthma. The roots and lower parts of the stems only should be used ; these should be cut small and put into a tobacco pipe, and the smoke must be swallowed together with the saliva produced; after which the person will, in a few minutes, be reliever, and will probably drop into a comfortable sleep, from which he will awake generally recovered. He must avoid drinking with the pipe, but afterwards a cup of coffee will be found highly refreshing. Under a vain idea of curing consumption, \&c. this plant has been incautiously used as tea, and in some instances has proved speedily fatal.

15 The seeds, the leaves, and the roots of this plant, taken in- 
Solanum Dulcamara. Bitter-sweet, orWoody Nightshade.

Common in hedges. The var. flor. albo. "Street at Ryde." D. Turner. ${ }^{16}$

nigrum. Common Garden Nightshade.

In gardens about Godshill. W.D. Snooke. ${ }^{17}$

Curronia Centaurium. Common Centaury ${ }^{18}$.

In pastures, and road sides. A var. flor. albo.

Pastures on the south of Newport.

- pulchella. Little Centaury.

"Ryde." S. Woods.

littoralis. Dwarf Tufted Centaury.

Sea banks near Compton.

ternally, sometimes priluce madness, convulsions, and death. The Edinburgh College order the expressed juice to be evaporated to an exiract; and in this state it may be advantageously joined with Opium, where the effects of that medicine are desirable, and costiveness to be avoided. There is no doubt of its being a useful medicine under proper management: the dose is from half a seruple to half a dram.

${ }_{16}$ Boerhaave reports it to be a medicine far superior to Sarsaparilla, as a swectener and restorative. The root has the smell of the potatoe.

17 From one to three grains of the leaves of this plant infused in boiling water, and taken at bed-time, occasion a copious perspiration, and generally purge more or less the following day. But its effects on the nervous system are so uncertain, and often so considerable, that it must be administered with the greatest caution. The flowers smell like musk.

18 This plant is extremely bitter. It is the basis of the famous Portland Powder, which prevents fits of the gout, when taken in large quantities and a long time tegether; but brings on hardness of the liver, palsy, and apoplexy. 
Viola hirta. Hairy Violet.

About Carisbrooke and Newport; and common in most parts of the island.

- odorata. Sweet Violet.

Common in most parts of the island.

— palustris. Marsh Violet.

Marsh on Apse Heath.

- canina. Dog's Violet. Var. 3. Cream-coloured Violet. (V. lactea, Fl. Brit. and E. Bot.)

Inclosures about Parkhurst Barracks. Samolus Valerandi. Water Pimpernel.

Banks in Colwell Bay; and in the marsh at Freshwater Gate, plentifully. ${ }^{19}$

Tuesium linophyllum. Bastard Toad-flax.

Spit at Norton Banks near Colwell. Brading

Downs. Afton and Freshwater Downs in great abundance. First noticed by Dr. Stokes.

Vinca niajor. Greater Periwinkle.

Between Cowes and Newport. Norton. Between

Colwell and Weston; and many other parts of the island. South of Yarmouth, plentifully.

First noticed by Withering.

Chenopodium rubrum. Sharp-pointed Blite.

Freshwater Gate.

murale. Thick Shining Blite.

Newport, Freshwater, Sandown, \&c. in plenty.

19 This plant is found in almost every part of the globe, and under very different latitudes. This circumstance, however uncommon with plants as well as animals in general, happens to several aquatics. 
Chenopodium polyspermum. Upright Blite.

East bank of the Medina below Copping's Bridge. Atriplex portulacoides. Shrubby Orache, or Sea Purslane.

Yarmouth, and Brading Harbour, in great plenty.

- laciniata. Frosted Orache.

Yarmouth, sparingly.

littoralis. Grass-leaved Sea Orache.

Coast nearCowes; and most other parts of the coast. Humulus Lupulus. Common Hops ${ }^{20}$.

About Newport, Steephill, \&c. in the hedges rather common.

Beta maritima. Sea Beet.

Common on every part of the coast.

Gextiana amarella. Autumnal Gentian, or Felwort.

Banks between Norton and Totland. Shide chalkpit, and on all the chalky downs throughout the island.

campestris. Field Gentian.

Heathy pasture between Colwell and Weston, plentifully.

Eryngiug maritimum. Sea Holly.

Shore near East Cowes. Norton Spit; and Dover Spit, in great plenty.

20 The English learned the use of hops from some native of Artois in the beginning of the sixteenth century; but for a long time after that, the addition of them to beer was held to be an adulteration of that liquor. A pillow filled with hops is reported to produce comfortable repose in cases where opiates have failed. The bine or straw of hops contains an excellent hemp for making cloth, canvass, ropes, and the very best materials for the manufacture of all kinds of paper. 
Caucalis nodosa. Knotted Stone Parsley.

Freshwater Down.

Conium maculatum. Common Hemlock ${ }^{21}$.

Hedges, amongst rubbish, \&c., not very common.

Crithaum maritimum. Sea Samphire.

Chalky cliffs from Compton westward. Bembridge Cliffs. First noticed by D. Turner.

Sisov Amomum. Bastard Stone Parsley.

About Newport, and common in most parts of the island.

segetum. Corn Parsley, or Stonewort.

In corn fields, generally in abundance.

CEsaxthe: fistulosa. Water Dropwort.

Marsh at Freshwater Gate. Withering. crocata. Hemlock Dropwort ${ }^{22}$.

Medina near Newport, in plenty. pimpinelloides. Parsley Dropwort.

Banks near Cowes. Freshwater. In the marsh at the head of the Yar, in plenty. "Near Ryde." S.Woods.

21 The whole plant is poisonous, and many instances are recorded of its deleterious effects; but modern experience has proved it to be less virulent than was formerly imagined: and though it may not cure cancers, it is certainly a very useful medicine when properly prepared.

22 The whole of this plant is poisonous, and the root is said to be the most virulent of all the vegetable poisons in Britain. Four spoonfuls of the juice occasioned the death of a person at Havant in 1758 . 
Smynium Olusatrum. Common Alexanders.

About Yarmouth, Norton, and Thorley. By the marsh below St. Helen's, in plenty.

Apium graveolens. Smallage, or Wild Celery.

About Newport, Yarmouth, and Bradirg.

Egopodium Podagraria. Gout-weed, or Ash-weed.

Between Buccomb and Shorwell. Norton. Freshwater.

Viburnum Lantana. Mealy Guelder Rose.

Common in the hedges.

Sambucus Ebulus. Dwarf Elder.

Between Newport and Carisorooke Castle.

"Between Luccomb and Bonchurch." S. Woods.

TAMar rx gallica. French Tamarisk.

Freshwater Gate. First noticed by Pulteney.

Statice Limonium. Lavender Thrift.

Yarmouth, and Brading Harbour, in abundance.

Linom usitatissimum. Common Flax ${ }^{23}$.

Places of growth not specified. Pulteney.

About Kennerley. W. D. Snooke.

- angusifolium. Narrow-leaved Pale Flax.

Near Ryde and Shanklin. About Colwell, Freshwater, Sandown, Kennerley, and most parts of the island.

23 This valuable plant originally came from those parts of Egypt which are exposed to the inundations of the Nile. The seeds yieid the linseed-oil in large proportion; and the remaining part is made into oil-cake, which is useful to fatten cattle. The fibres of the stein are manufactured into linen. 
Lixum Radiola. All-seed Flax. (Radiola millegrana, Fl. Brit.) Heath at Colwell in spots from which the turf has been removed. Between Newport and Godshill near Bohemia. W. D. Snooke.

Cuscuta europaea. Greater Dodder.

"At Lake." Mr. J. Woods jun.

\section{HEXANDRIA.}

Screls autumnalis. Autumnal Squill.

Dover Spit in the greatest abundance.

"Priory." J. Woods jun.

verna. Vernal Squill.

"Near Newport." Pulteney.

Asparagus officinalis. Common Asparagus.

Norton Spit. "Freshwater." Pulteney.

Tasus communis. Black Bryony, or Ladies' Seal.

In hedges and thickets, common.

Juncus maritimus. Sea Hard-rush.

Norton, and Brading Harbour, in abundance.

Forsteri. Narrow-leaved Hairy-rush.

"Wood between Ryde and Newport, and at

Shanklin." D. Turner.

Remex aquaticus. Great Water Dock.

Marsh near Easton, in plenty.

- pulcher. Fiddle Dock.

About Freshwater, Yarmouth, and Afton.

Azissa ranunculoides. Small Water Plantain.

Ditches in the marsh near Easton. First noticed by $D$. Turner. 


\section{OCTANDRIA.}

Epilobium tetragonum. Square-stalked Willow-herb.

Near Cowes, Newport, and Sandown, in abundance.

Chlora perfoliata. Yellow Centaury.

Banks near Cowes. Colwell. Carisbrooke Castle.

Shanklin, \&c. in plenty. First noticed by

Pulteney. Ventnor Cove. W.D. Snooke.

Erica vulgaris. Common Heath ${ }^{24}$.

Bleak Down. Wroxall Down. Common in many places.

Var. flor. albis, place not specified. Pulteney.

- cinerea. Fine-leaved Heath.

Var. flor. albis, place not specified. Pulteney.

- Tetralix. Cross-leaved Heath.

Var. flor. albis, place not specified. Pulteney. Polygonum pallidum. Pale-flowered Persicaria.

Freshwater and Colwell.

Myriophyllum spicatum. Feather Pond-weed.

Near Colwell. Ditches about Sandown, in plenty.

24 Woollen cloth boiled in alum-water, and afterward in a strong decoction of the tops of heath, comes out a fine orangecolour. The stalks and tops will tan leather. In the island of Ilay, ale is frequently made by brewing one part malt and two parts of the young tops of heath; sometimes hops are added. 


\section{DECANDRIA.}

Monotropa Hypopitys. Yellow Bird's-nest.

"By the foot-way under the cliff from Luccomb to Bonchurch." J.Woods jun.

Silene anglica. Small Corn Campion, or English Catchfly.

Fields between Lake, Sandown and Shanklin.

Near Princeslade. "Near Newport." Curtis.

maritima. Sea Campion, or Catchfly.

Shore near Egypt. Dover Point, sparingly.

Stellaria holostea. Greater Stitchwort.

Hedges and woods, common.

Arenaria rubra. Purple Spurrey, or Sandwort.

About Sandown, plentifully.

Sedum anglicum. English Stonecrop.

Warren in Freshwater. Sandown Bay. Dover

Spit, in plenty.

- reflexum. Sengreen.

Roof of a cottage at Easton. Sandown Fort.

Lychesis dioica. Red Campion.

Hedges, common. Var. flor. albis, or White Campion.

In fields by French Mill near Godshill. $W, D$. Snooke.

Cerastium aquaticum. Marsh Mouse-ear.

By the Medina, a little below Shide, sparingly.

tetrandrum. Stitchwort. (Sagina cerastoides, Withering.)

Afton Down by the sea. "High downs at Freshwater." D. Turner. 
Spergula arvensis. Corn Spurrey. Var. 1. (S. pentandra, E. Bot.)

Field east of Colwell. Near White Cross. nodosa. Knotted Spurrey.

Shore at Norton. Marsh near Compton.

\section{DODECANDRIA.}

Lythrum Salicaria. Loosestrife.

Abundant about Newport, Freshwater, and other places.

Agrimonia Eupatoria. Common Agrimony.

Hedges and shady places, common.

Reseda Luteola. Wild Woad, or Dyer's Weed.

Shide Chalk Pit. About Carisbrooke, \&c. in abundance.

FAgus sylvatica. Beech Tree ${ }^{25}$.

Woods and hedges common.

25 This tree is difficult to transplant. It bears lopping, and may be trained to form very lofty hedges. The wood is strong, though rather brittle; it soon decays in the open air, but endures long under water. It is excellent fuel, and when burnt affords a large quantity of pot-ash. The leaves taken in autumn, before they are much injured by the frosts, make infinitely better mattresses than straw, and last for seven or eight years. The nuts eaten occasion head-ache; but well dried and powdered, make wholesome bread: they are sometimes roasted, and substituted for coffee.

The beautiful variety with purple foliage may be propagated by engrafting on the common stock, and is very ornamental in shrubbery grounds. 
Euphorbia portlandica. Portland Spurge.

Near the cliffs at the eastern extremity of Sandown Bay, in plenty.

platyphylla. Warty Spurge.

About Colwell. Observed also near Brading, \&c. amygdaloides. Wood Spurge.

Hedges and copses near Newport; and most other parts of the island, in abundance.

\section{ICOSANDRIA.}

Pruxus insititia. Black Bullace Tree.

Hedges near Hill Farm. Princeslade and several other places.

Spirea Ulmaria. Meadiow-Sweet.

Moist meadow-banks in several of the central parts of the island.

Rosa tomentosa. Downy-leaved Dog Rose.

Place of growth not specified. S. Woods.

Potentilla anserina. Silver-weed, or Wild Tansey.

Sides of paths, common. reptans. Common Cinquefoil.

Pastures and road sides.

Tormentilla officinalis. Septfoil.

Barren pastures and road sides.

Geum urbanum. Conmon Avens.

Woods and hedges.

Comarum palustre. Marsh Cinquefoil.

Marsh near Easston, in plenty. 
Pyrus domestica. True Service-tree.

Frequent in the island.

- Aria. White Beam-tree.

Near Brading. Mr. S. Woods.

\section{POLYANDRIA.}

Chelidonium luteum. Yellow-horned Poppy, or Sea Celandine.

Near Cowes, Steephill, and Ventnor, and most other parts of the coast.

Papaver Argemone. Long Rough-headed Poppy.

Fields between Lake and the sea.

- dubium. Long Smooth-headed Poppy.

About Carisbrooke Castle. About Shanklin Chine, and in pastures in various parts of the island.

Cistus Helianthemum. Dwarf Cistus, or Little Sunflower.

Near Brading and Yaverland. Apse Hill. Downs near Freshwater.

Var. petalis basi aurantiis, "Chalk-pit near Carisbrooke Castle." D. Turner.

Ancilegia vulgaris. Columbine.

Hedge east of Colwell Barracks. Ranuxculus Flammula. Little Crowfoot ${ }^{26}$.

Plentiful about Freshwater, and several other parts of the island.

26 It is very ncrid. Beaten to a pulp or paste, with a little mustard, it makes a good blistering plaster. "The distilled water of this plant operates as an emetic the instant it is swallowed: and 
Ranunculus Lingua. Great Crowfoot.

Marsh near Easton, in plenty.

- parviflorus. Small-flowered Crowfoot.

"Freshwater, by the Cliffs." D. Turner.

- hederaceus. Ivy-leaved Crowfoot.

In a pond near Pann. Weston. St. Helen's, \&c.

Arus maculatum. Wake Robin, or Cuckowpint ${ }^{27}$.

Ditch-banks, and shady places.

\section{DIDYNAMIA.}

Teucrium Chamæedrys. Wall Germander.

" Carisbrooke Castle." Pulteney.

Nepeta cataria. Nep, or Cat-mint.

Gravel-pit near Calbourne Bottom. Weston Farm. Sconce Tower.

Mentha sylvestris. Horse-mint.

Noticed by Mr. S. Woods.

from the experience I have had of it, I feel myself authorized to assert, that in the case of poison being swallowed, or where there is a necessity of making a patient vomit instantaneously, it is preferable to any other medicine yet known, and does not excite those painful contractions in the upper part of the stomach which the white vitriol sometimes does." Withering.

27 The root and leaves, when recent, are extremely acrid. The root dried and powdered is used by the French to wash the skin, and is sold under the name of Cypress Powder. It is undoubtedly a good and an innocent cosmetic. Starch may be made from the roots. 
Mentina rotundifolia. Round-leaved Mint.

Road side near Colwell Barracks. "In the Undercliff between St. Lawrence and Niton." J. Woods jun.

- piperita. Pepper-mint.

By the side of the Medina, below Shide. "Near Ryde." J. Woods jun.

Galeobdolon luteum. Yellow Dead Nettle.

By the wood-side beyond Apse Hill. Dr. Moore. Ballota nigra. Stinking Horehound.

Var. $\beta$ between Freshwater Gate and Farringford Hill.

Marrubium vulgare. White Fiorehound.

Abundant on all the downs west of Calbourne.

Sandown. Colwell.

Origanum vulgare. Wild Marjoram ${ }^{28}$.

Carisbrooke, and the Castle. Brading and Yaver-

land in abundance. Steephill, \&c.

Тнумus acinos. Basil Thyme.

About Carisbrooke Castle. Near Princeslade.

Calamintha. Calamint.

About Carisbrooke village and castle. Near some cottages at Thorley, in plenty.

Scuteldaria galericulata. Blue Scull-cap.

By the Medina between Newport and Shide, sparingly.

\$s 'The whole plant is a warm aromatic. The dried leaves, used instead of tea, are exceedingly grateful. The essential oil of this plant is so acrid that it may be considered as a caustic; dropt on cotton, and put into a hollow aching tooth, it frequently relieves the pain. 
Scutellaria minor. Little Scull-cap.

Bog on Apse Heath, in abundance.

Eupurasia officinalis. Common Eyebright.

Pastures and road sides in many places.

Var. flor. purpureis, Colwell Heath.

odontites. Red Eyebright.

Meadows and pastures, common.

Melampyous pratense. Common Yellow Cow-wheat.

Copse by the Medina below Newport, in plenty.

By the Inn near Lord Dysart's.

Scrophularia aquatica. Water Betony.

About Newport, Freshwater, \&c.

Antirrainum repens. Pale Blue Toadflax, or Creeping Snapdragon.

Hedges near West Cowes, in abundance.

minus. Little Snapdragon.

Shide Chalk-pit, in plenty. Fields near Tapnell. mrijus. Great Snapdragon.

Yarmouth Castle, and many other old buildings in various parts of the island. Orontium. Calf's-snout Snapdragon.

Fields between Lake and Sandown. Fields between Week Farm and St. Lawrence. W. D. Snooke. Digitalis purpurea. Purple Foxglove ${ }^{29}$.

Common by the hedges in most parts of the island. Orobanche carulea. Purple Broom-rape. "Steephill." Pulteney.

20 This is certainly a very active medicine. As a remedy in 


\section{TETRADYNAMIA.}

Bunias Caliile. Sea Rocket.

Sandown Bay in abundance; and most other parts of the coast.

Thlaspr campestre. Mithridate Mustard, or Bastard Cress.

Between Cowes and Newport.

Cochlearia danica. Danish Scurvy-grass.

"Near the Reedles. High Down and Weston Down by Freshwater." D. Turner.

anglica. English Scurvy-grass.

Yarmouth. First noticed by Dr. Stokes.

Cheirartius fruticulosus. Wild Wall-flower.

Carisbrooke Castle, and on most old buildings in the island ${ }^{30}$.

Hesperis inodora. Dame's Violet.

"Bonchurch, sparingly." D. Turner.

Turritis hirsuta. Wall Cress.

"Carisbrooke Castle Hill, and High Down by Freshwater." D. Turner.

Sivapis alba. White Mustard.

Freshwater.

dropsy, particularly that hitherto almost incurable disease Hydrot:Icrax, its importance has been amply ascertained. It has more recently bcen employed as a sedative, and has proved scrviceable in retarding the undue quickness of the pulse, in many cases of pulmonary consumption.

3) The cliffs from Compton to Freshwater Gate are covered by a Cheiranthus not easily accessible, probably $C$. sinuatus. 
Sinapis nigra. Common Mustard.

About Yarmouth and Norton.

\section{MONADELPHIA.}

Geranium columbinum. Long-stalked Crane's-bill.

Observed in one or two places in West Medina.

- lucidum. Shining Crane's-bill.

Between Newport and the Barracks.

Altura officinalis. Marsh Mallow.

Coast near West Cowes. Abundant about Norton and Freshwater.

Malva moschata. Musk Mallow.

Between Cowes and Newport. Between Carisbrooke and Swainston, sparingly.

Lavatera arborea. Sea Tree Mallow, or Lavatera.

Sandown Fort, plentifully; and about Sandown Cottage. Sea coast near Ryde.

\section{DIADELPHIA.}

Fumaris capreolata. Ramping Fumitory.

Near the entrance to Apse Heath, in plenty.

claviculata. White Fumitory.

Polygala vulgaris. Milkwort '.

By the road side on Kennerley Heath near Rookley. W. D. Snooke.

32 Linnzus found this plant to possess the properties of the Senega Rattlesnake roots (Polygala Senega), but in an inferior c 2 
Spartium scoparium. Common Broom.

Shanklin Chine; and near Ryde, plentifully.

Genista tinctoria. Dyers' Green-weed.

Sea banks near Cowes and Colwell, in abundance.

Between Brading and St. Helen's.

- anglica. Needle Furze.

Heath by Colwell Barracks.

ULEX nanus. French Furze.

As abundant on the heaths as the $U$. europaus.

Ononis arvensis. Hairy Rest-harrow.

Var. $\beta$. Between Brading and St. Helen's.

Pisum maritimum. Sea Pea.

"Sandown Beach." Pulteney.

Latimrus sylvestris. Narrow-leaved Everlasting Pea.

Below the cliffs at Shanklin and Luccomb, in abundance.

latifolius. Broad-leaved Everlasting Pea.

"Sandown Beach." Pulteney.

Hippocrepis comosa. Tufted Horse-shoe Vetch.

About Carisbrooke Castle; and on all the chalky downs.

Astragalus hypoglottis. Purple Mountain Milkwort.

Dover Spit, in plenty.

"Carisbrooke Castle Hill." Mr. Griffith.

'Trifolium scabrum. Rough Trefoil.

High Down by Freshwater. First noticed by

D. Turner.

degree. An infusion of the herb, which is very bitter, taken in a morning fasting, about a quarter of a pint daily, promotes expectoration. 
Trifolivm arvense. Hare's-foot Trefoil.

Dover Spit, in plenty.

- medium. Zig-zag Trefoil.

Banks near Cowes.

fragiferum. Strawberry-headed Trefoil.

Abundant about Cowes, Newport, and most parts of the island.

Lotus corniculatus. Bird's-foot.

By the road sides very common.

Var. $\beta$. "Hedges between Newport and Arreton."

D. Turner.

Medicago polymorpha. Snail-shell Medick, or Heart Trefoil.

Parapet of Yarmouth Castle. Norton, \&c.

\section{POLYADELPHIA.}

Hypericey Androsamum. Tutsan.

Sandown Cottage, Steephill. Between Luccomb and Bonchurch.

- humifusum. Trailing St. John's Wort.

Colwell Heath. Near West Cowes. Parkhurst Heath, \&c.

- hirsutum. Hairy St. John's Wort.

About Carisbrooke and the Castle. Between Apes Hill and Swainston, in plenty.

\section{SYNGENESIA.}

Hieracium sabaudum. Shrubby Hawkweed.

Wood near Rỵde. c 3 
Hieracium umbellatum. Bushy Hawkweed.

Near Princeslade; and on Apse Heatlr.

Cichorium Intybus. Wild Succory, or Endive.

In a field between Cowes and Newport.

Serratula tinctoria. Common Saw-wort.

Copses and heaths, abundant.

Carduus tenuiflorus. Slender-flowered Thistle.

On the chalky downs in West Medina, in plenty.

"Every where about Freshwater." D. Turner.

nutans. Musk Thistle.

Very abundant on the Downs.

"eriophorus. Woolly-headed Thistle.

"Between Luccomb and Bonchurch." J. Woods jun.

- pratensis. Meadow Thistle.

Road side between Tapnell and the Finger Post, at the meeting of the Freshwater and Yarmouth roads. First noticed by D. Turner.

— acaulis. Dwarf Thistle.

About Carisbrooke Castle; and on all the calcareous downs, in plenty.

Carlina vulgaris. Wild Carline Thistle.

Carisbrooke Castle; and on all the chalky downs. Bidens cernua. Water Agrimony.

By the side of the Medina near Newport. Marsh near Easton, in great abundance.

Eupatorium cannabinum. Hemp Agrimony.

Ditch banks and road sides, common. Santorina maritima. Seed Cotton Weed.

Shore at Sconce Tower. 
Artemisia maritima. Sea Southernwood.

Near East Cowes, and about Brading Harbour, in plenty.

carulescens. Blueish Southernwood.

On the coast of Brading Harbour, near Broad Stone. Gxaphalius rectum. Upright Cudweed.

"Frequent in the south-west parts of the island."

J. Woods jun.

Conyza squarrosa. Great Fleabane.

About Carisbrooke and the Castle. Near Brading,

Yaverland, and Ryde.

Erigeron acre. Blue Fleabane.

About Colwell Barracks, in plenty. Near Whitecross.

Tussilago Farfara. Common Colt's-foot ${ }^{32}$.

Too well known to many farmers on moist and stiff soils.

Senecio sylvaticus. Bushy Groundsel.

About Colwell Barracks. Sandown Bay. Between

Apse Heath and Lake. Below Shanklin.

- tenuifolius. Hoary Groundsel.

Very common in most parts of the island.

Solidago virgaurea. Common Golden Rod.

Colwell Heath. Apse Heath, \&c.

32 This is the first plant that vegetates in marl or limestone rubble. The downy substance on the under surface of the leaves, wrapped in a rag, dipped in a solution of saltpetre and dried in the sun, makes the best tinder. The leaves are the basis of the British herb tobacco. It may be destroyed by cutting off the crown of the root in March. 
InvLA Helenizm. Elecampane.

About Weston Farm. Near Ashey. Freshwater.

Cineraria integrifolia. Mountain Fleawort.

"Belhan." Pulteney.

Matricaria Parthenium. Common Feverfew, or Featherfew. (Pyrethrum Parthenium, E. Bot. and Fl. Brit.)

Shanklin Chine, \&c.

maritima. Sea Feverfew. (Pyrethrum maritimum, E. Bot. and Fl. Brit.)

Near Cowes ; and on most parts of the coast.

Anthemis arvensis. Corn Chamomile.

Plentiful about Colwell, and most parts of the island. nobilis. Common Chamomile ${ }^{38}$.

Grassy parts of Parkhurst Heath. Colwell Heath. Apse Heath. Royal Heath, \&c. in great abundance.

Achillea Ptarmica. Sneeze-wort Yarrow.

About the Depôt Hospital.

Centaurfa Scabiosa. Greater Knapweed.

Near Newport. Carisbrooke. Lake. Borders of cornfields, common.

33 The leaves and flowers have a strong, not ungrateful smell, and a bitter nauseous taste. They afford an essential oil. An infusion of the flowers is often used as a stomachic, and as antispasmodic. In large quantities it excites vomiting. The powdered flowers in large doses have cured agues, even when the Bark had failed. Both the leaves and flowers are used in antiseptic fomen. tations and poultices. From their antispasmodie powers they are frequently found to relieve pain, either applied externally, or taken internally. Ray recommends the flowers in calculous cases. 


\section{3}

\section{CRYPTOGAMIA.}

Equisetum arrense. Common Horsetail.

Moist cornfields, gardens, \&c.

- Aluviatile. River Horsetail.

By the sides of rivers and wet ditches. In a ditch at Lake, near Gatcombe.

Osmunda regalis. Royal Moonwort. Pulteney. Asplenium Scolopendrium. Spleenwort, or Hart's Tongue.

On hedge banks in many places.

Lichen crenularius. Rusty-shielded Lichen.

On flints on the highest parts of the island.

- atro-albus. Spotted Lichen.

The habitat the same as the crenularius.

Ulva dichotoma. fistulosa. $\}$ Shores of the island. E. Forster jun.

Fucis reniformis. Kidney-shaped Fucus.

At Niton in the sea. Miss E. Everett.

- Hypoglossum $\beta$.

A common parasitical plant on the stems and tips of other Fuci. Stackhouse.

- obtusus.

_

— bifidus $\delta$.

_ ciliatus $\beta$.$\} Shores of the island. Mr. Maimburg.$

edulis.

At Freshwater Gate. Mr. E. Forster jun. 
Fúcus cartilagineus.

Freshwater Bay. Dr. Withering.

- coronopifolius.

Shores of the island. Miss E. Everett.

- pinastroides.

At Freshwater Gate. Mr. E. Forster jun.

- subfuscus.

$\left.\begin{array}{l}\text { confervoides } \varepsilon . \\ \text { Opuntia. }\end{array}\right\}$ Shores of the island. Mr.Maimburg.

Conferva equisetifolia.

Noticed by Mr. E. Forster jun.

\section{EXOTIC PLANTS}

GROWING IN THE OPEN AIR.

The climate of the Isle of Wight is so favourable to vegetation, that the following Exotic Plants, natives of hot climates, and cultivated only in greenhouses in other parts of England, among others are to be found growing in the open air in the garden of Mr. Nash, near East Cowes.

Pittosporum Tobira. Native of China, stands out very well in the flower-garden. Soil, loam and bog. Edwardsia grandiflora, or microphylla. Native of New Zealand, will stand out. Soil, loam and bog. Pomegranate, common double-flowered. Native of the South of Europe, stands out and flowers well. 


\section{5}

Myrtees of all sorts. Native of the Suuth of Europe, stand out well. More sorts at Mr. Nash's than any other place in the island.

Rosa multiflora, or bracteata, with many others. Natives of China, and stand out very well.

Совса scandens. Native of Mexico, a great climber, to be raised from seed in March, and kept in a pot till the latter part of April, then turned out, and it will run thirty feet or more. Soil, rotten leaf mold and loam, or rotten dung and common garden soil.

Pyrus Japonica. Stands out without the least protection in winter. Soil, bog and loam.

HYDRANGEA hortensis. Native of China, stands out well. Soil, bog and loam. Set young plants that have not blossomed, in all bog mold, and they will flower blue or purple.

Aucuba Japonica. Soil, bog and loam. Will do well in a north aspect and moist situation.

Camelia, single red, stands out well.

ThEs viridis, or Bohea. Native of China, stands out well.

FINIS.

Printed by Richard ' laylor,

Shoe-lane, London. 


